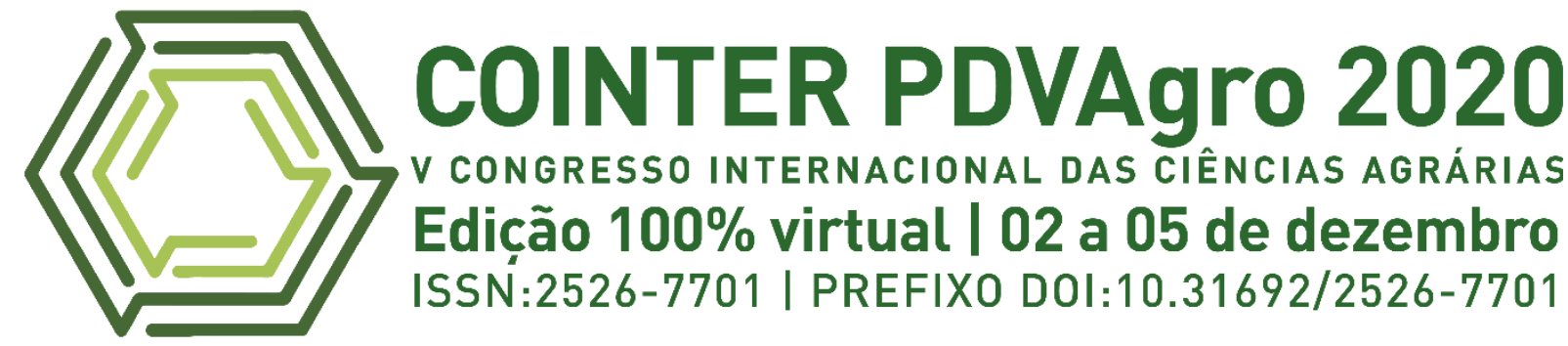

\title{
PROBLEMS CONCERNING DORMANCY AND ITS INVESTIGATION IN HOG PLUM (SPONDIAS MOMBIN LINN.): A REVIEW
}

\section{IMPASSES ENVOLVENDO A DORMÊNCIA E SUA DETECÇÃO EM TAPEREBAZEIROS (SPONDIAS MOMBIN LINN.): UMA REVISÃO}

\section{PROBLEMAS RELACIONADOS CON LA DORMANCY Y SU INVESTIGACIÓN EN HOG PLUM (SPONDIAS MOMBIN LINN.): UNA REVISIÓN}

\author{
Presentation: Oral Communication
}

Carlos Augusto Cavalcante de Oliveira ${ }^{1}$; Rafael Moysés Alves ${ }^{2}$

DOI: https://doi.org/10.31692/2526-7701.VCOINTERPDVAgro.0163

\begin{abstract}
The Hog Plum is a fruit tree native to Brazil. The species has great nutritional, medicinal as well as ecologic importance, so that it has an outstanding role in the maintenance of health and, as in association with other species, in the restoration of degraded areas. Despite this, large impasses are still found for its commercial establishment due to the strong dormancy present in this specie. This analysis aimed to infer, from the experimental researches available in the scientific literature, the most likely candidates as the causer of dormancy existing in Yellow Mombin endocarps. In addition, some recommendations for the publication of papers on the subject are also outlined. In the dormancy classification system, there are 3 hierarchical layers: classes (5 in total), within each class there is a certain amount levels (varying according each class), and within each level, there may or may not be types. To obtain the papers, several data platforms (both in English and Portuguese) were used using keywords to direct and obtain more specific and applicable results. The results show that mechanical dormancy may not be the only cause of dormancy in the species. More recent investigations on the subject have pointed out that physical dormancy, as well as combinational, is not present. As far as the published works reach, non-profound physiological dormancy is possible and consistent with the available literature, however, there is evidence that morphological dormancy is also present. Furthermore, it was possible to realize that a Deep Simple level of morphophysiological dormancy is coherent to the revised literature. Based on the information collected and discussed, it is possible to infer simple deep morphophysiological dormancy as a cause of the low germination rates found.
\end{abstract}

Keywords: Dormancy, Hog Plum, Germination.

\section{RESUMO}

O taperebazeiro é uma frutífera nativa do Brasil. A espécie possui grande importância nutricional, medicinal bem como ecológica, sendo muito importante na manutenção da saúde humana e, quando em associação com espécies secundárias, na restauração de áreas degradadas também. Apesar disso,

\footnotetext{
Agronomia e Bolsista PIBIC Embrapa, Universidade Federal Rural da Amazônia, augustocavalcantecarlos@gmail.com.br

Ph.D. em Melhoramento e Genética de Plantas e Pesquisador, Embrapa Amazônia Oriental, rafaelmoyses.alves@embrapa.br
} 
grandes impasses ainda são encontrados para o seu estabelecimento comercial devido à forte dormência característica da espécie. Este artigo teve como objetivo inferir, a partir de trabalhos experimentais disponíveis na literatura científica, os candidatos mais prováveis como agentes causadores da dormência presentes em endocarpos de Taperebá. Além disso, algumas recomendações para a publicação de trabalhos sobre o assunto também são delineadas. No sistema de classificação de dormência, existem 3 camadas hierárquicas: classes (5 no total), dentro de cada classe existem uma quantidade determinada de cada níveis (diversos), e dentro de cada nível podem ou não existir tipos. Para a obtenção dos artigos, utilizou-se diversas plataformas de dados (tanto na língua inglesa quanto portuguesa) usando-se palavras-chaves para direcionar e obter resultados mais específicos e aplicáveis. Os resultados mostram que a dormência mecânica não pode ser a única causa da dormência na espécie. Investigações mais recentes sobre o tema, tem apontado que a dormência física assim como a combinacional não estão presentes também. Quanto a dormência fisiológica não profunda, é possível e coerente com a literatura disponível, no entanto existem evidências de que a dormência morfológica também está presente. Além disso, foi possível detectar que o nível profundo simples da dormência morfofisiológica é coerente com a literatura revisada. Baseado nas informações coletadas e discutidas, é possível inferir a dormência morfofisiológica profunda simples como causa dos baixos índices germinativos encontrados.

Palavras-Chave: Dormência, Taperebazeiro, Germinação.

\section{RESUMEN}

El taperebazeiro es un árbol frutal nativo de Brasil. La especie tiene una gran importancia ecológica y nutricional, siendo muy importante cuando se asocia con especies secundarias en la restauración de zonas degradadas y también en el mantenimiento de la salud. A pesar de esto, grandes impases todavía se encuentran para su uso en áreas de degradación debido a la fuerte latencia característica de la especie. Este artículo tenía como objetivo inferir, a partir de los estudios experimentales disponibles en la literatura científica, los candidatos más probables como causadores de la inactividad fuerte presentes en los endocarpos taperebá. Además, también se describen algunas recomendaciones para la publicación de documentos sobre el tema. En el sistema de clasificación de latencia, hay 3 capas jerárquicas: clases ( 5 en total), dentro de cada clase hay una cierta cantidad de cada nivel (diverso), y dentro de cada nivel puede o no puede haber (varios) tipos.. Para obtener los artículos, se utilizaron varias plataformas de datos (tanto en inglés como en portugués) utilizando palabras clave para dirigir y obtener resultados más específicos y aplicables. Los resultados muestran que el entumecimiento mecánico puede no ser la única causa de latencia en la especie. Investigaciones más recientes sobre el tema han señalado que el entumecimiento físico, así como la combinación no está presente. La latencia fisiológica no profunda es posible y consistente con la literatura disponible, sin embargo hay evidencia de que el entumecimiento morfológico también está presente. Además, fue posible detectar que el nivel profundo simple de inactividad morfofisiológica es consistente con la literatura revisada. Sobre la base de la información recopilada y discutida, es posible inferir la latencia morfofisiológica profunda simple como causa de las bajas tasas de germinación encontradas.

Palabras Clave: Dormancy, Taperebazeiro, Germinación.

\section{INTRODUCTION}

Hog Plum is a common fructiferous, localized in several Brazilian regions, especially in the Northeast and North regions, where it is mainly consumed raw, however, it has great market potential, once researches have been pointing out that beverages based on this fruit has good reception of customers audience (SOUZA et al., 2020) and it holds outstanding nutritional properties (MATTIETO et al., 2010; TIBURSKI, 2011; FADIMU et al., 2012; 
SOUZA et al., 2020). Furthermore, the specie has ecologic importance due to its utilization to the restoration of degraded riparian forests (VALE; COSTA; MIRANDA, 2014).

Besides, some medicinal properties have been reported in leaves of this specie (CORTHOUT et al., 1991; AYOKA ET AL., 2005; ABIODUN et al, 2006; ADEDIWURA AND KIO, 2009; AYOKA et al., 2010; OSUNTOKUN et al, 2018; INNIH, OMAGE, OMAGE, 2020). Furthermore, S. mombin is often present in African countries such as Nigerian, where it is used as a feed resource, antiseptic soap, avoiding cough, malaria, as well as stomachal aches. (ADEDOKUN et al., 2010).

Yellow mombin is arboreal plant reaching up to 30 meters turning on its raising spot (wild or domestic), whose diaspore show a pulpy mesocarp covered by orange-colored or yellowish thin bark. The reproductive period only begins 3 years after his sown. Adler and Kielpinski (2000), over a phonologic analyze, realized that the fructification proportion of the plant changes according the gathering site, years and individual size. About the biometric characteristics, Carvalho et al. (2011) noted that mean weight of some cultivars studied range among 6,15 to $18,82 \mathrm{~g}$, the length reaching 26,43 to $38,87 \mathrm{~mm}$, and width range between 21.59 and $30.71 \mathrm{~mm}$. Concerning the endocarp, the mean weight found, in a work with five genotypes, reach from 0.51 to $2.242 \mathrm{~g}$, the length 2.47 to $4.32 \mathrm{~cm}$, and width 2.01 to $2.66 \mathrm{~cm}$ (QUADROS et al., 2015). This fruit can be propagated by sexual and asexual methods. The first method is not widely used for the formation of commercial orchards due to genetic variability it entails. A sexual propagation, through grafting, has been the preferred method, for promoting greater homogeneity to plants. However occasionally, the cutting has been used. Souza and Lima (2004) observed, in a study with cuttings at Embrapa Agroindústria Tropical, located in in Pacajus,CE, that the application of Indolbutyric Acid had little influence on the rooting of the piles, showing that there is a need to improve this method propagative.

Despite this, large-scale cultivation of this fruit is a challenge yet, mainly because its diaspores have strong dormancy, blocking the germination, and hindering the commercial establishment of crops. Some attempts to overrule this problem has been made (SOUZA et al., 2015; MARTINS et al, 2019), however its results are at best doubtful yet. Fuelling this issue, it is not clear what is the nature of this dormancy, therefore producers don't know what kind of pre-germinative treatment apply to overcome this problem. Further, the majority of the experimental papers published about this topic does not use the more useful and coherent classification system to dormancy (BASKIN and BASKIN, 2004), making the point less clear to identify what causes the dormancy. The purpose of this review is to analyse the 
experimental works made hitherto, and identify what is the nature of the dormancy in Hog Plum.

\section{THEORETICAL FOUNDATION}

It is an open-and-shut question that clarifying the definition used in some work is outstanding for any research. Therefore, forthcoming, some useful dormancy definitions will be given. Thereupon, a short historical approach concerning the relationship among growth regulator hormones and the dormancy process will be summarized. Further, we will describe how dormancy is divided into its respective classes, focusing on physiological dormancy and morphophysiological dormancy.

It is difficult to develop some ecumenic acceptable and coherent definition of dormancy, mainly because of the way used to identify it - count of non-germinating seed in greenhouse experiments -, what prone researchers to measure this phenomenon by the absence of germination. Baskin and Baskin (2004) has been proposing to define a dormant seed as "one that does not have the capacity to germinate in a specified period of time under any combination of normal physical environmental factors [...] that otherwise is favorable for its germination". Bewley (1997) has used a similar concept, however focusing on the failure of the germination process. It is contentious if that's a suiting manner to make it. FinchSavage and Leubner-Metzger (2006) propose to change our standard thinking of this, getting around the idea of germination, pointing that dormancy is a property of each seed and that is stated like this: "it is [dormancy] a characteristic of the seed that determines the conditions required for germination”. Henceforward, Finch-Savage and Leubner-Metzger`s definition will be used, albeit in some cases the former can be used, in which case it will be signed.

The prevailing mainstream regards two hormones as pivotal regulators of both dormancy and germination: Gibberellin and Abscisic Acid (KUCERA et al., 2005). However, how these hormones interact one each other is arguable yet. The firsts idea about this topic has pointed out that they act both simultaneously and antagonistically to regulate the germination and dormancy process. This has been called the "Hormone-Balance Model". Despite this, after all, it was modified- now being called "Revised Balance-Hormone Model" - due to some new researches using mutants of Arabdopsis thaliana (KARSSEN and LAÇKA, 1986). This works pinpointed that the two regulator hormones don not act supporting or cutting off the effect of each other. What really happens is that while Abscisic Acid act inflicting and maintaining dormancy in seed, gibberellin only stimulates the germination processes when Abscisic Acid level inside the seed is reduced, and the amount of 
this hormone to do so, depends on how much Abscisic Acid has in the seed (KARSSEN and LAÇKA, 1986). That is an important model to explain a lot of information built up about dormancy in Hog Plum that is not explained yet, therefore, this will be used posteriorly. However, there are new perspectives on this. Finch-Savage and Leubner-Metzger (2006) have indicated that it seems to be the $\mathrm{ABA}$ :GA ration, not the absolute content, which determines the germination and dormancy.

Sometimes, great advances in the scientific environment take place not only developing a hypothesis and carrying out experiments but proposing new ways to organize or thinking of some issues. Nikolaeva, a Russian seed physiologist, has made exactly that (Baskin and Baskin., 2008). She has classified dormancy in five classes concordantly its nature. However, Baskin and Baskin (2004) develop a newer and more coherent framework to explain dormancy. Their theoretical structure is divided into three hierarchical layers: classes, comprising levels, containing types. There are five classes: first, physiological dormancy, which is caused by some biochemical hindrance and can be divided in three levels - deep, intermediate and non-deep; second, morphological dormancy, which occur due the small size of the embryo, and, given enough time, it will develop and overcome the dormancy normally (there are any levels in this class); three, it is the morphophysiological dormancy, comprising both morphological and physiological dormancy, namely it is given rise by a biochemical impediment and the small size of the embryo, and there are eight levels here, being non-deep simple, intermediate simple, deep simple, deep simple epicotyl, deep simple double, non-deep complex, intermediate complex; four, physical dormancy, occurring because of some hindrance to water uptake in seed, avoiding germination process (ROLSTON, 1978), and, again, there are any levels in this classes; finally, combinational dormancy, which is, as I the morphophysiological case, a collusive process comprising both physical as well as physiological dormancy. This scheme has been used to the moist tropical forest of the Panama Canal Watershed (SAUTO et al., 2007) and has significant results. A summary is showed in the table below (chart 01) Despite the importance of all of this dormancy causes, morphophysiological dormancy in the most outstanding here because it can be applied to Hog Plum problem, as we will see later. Therefore, it is will be emphasized from now on, beginning describing physiological dormancy, and, in the end, it will be talking about morphophysiological dormancy. 
Chart 01: Summary and description of dormancy classes

\begin{tabular}{|c|c|}
\hline Classes of Dormancy & Description \\
\hline Physiological & Biochemical Block to Germination and Coat Resistence \\
\hline Morphological & Small Size of Embryo \\
\hline Morphophysiological & Physiological + Morphological \\
\hline Physical & Block to Water Uptake \\
\hline Combinational & Physiological + Physical \\
\hline
\end{tabular}

Source: Own Source (2020)

As we have seen in the paragraph before, physiological dormancy is a block to germination caused for some biochemical processes. The non-deep level will be analyzed. Different from all other levels, this dormancy is not a dichotomic phenomenon (dormant and non-dormant state). Actually, there is a continuum of dormancy state among the primary dormancy (caused over the seed development) and the secondary dormancy (which occurs after the dormancy was overruled), and each of these states is saying to be in "conditional dormancy". Furthermore, this dormancy can be boiled down in two components: the coat component, which imposes some kind of mechanical resistance to the radicle protrusion, and the embryo component, concerning the biochemical hindrance to germination. It is important to pinpoint that each of these components does not happen alone. The coat component only stops the germination whether the embryo has low potential to germinate, so that physiological dormancy is a joint action. As for the terminology question, the coat component of this dormancy is frequently called "Mechanical Dormancy". The most applicable way to detect this kind of dormancy is scarification and Gibberellin application (BASKIN and BASKIN, 2004), and, after, this information will be useful to point out the nature of dormancy.

Remembering, there are 8 levels of morphophysiological dormancy according to the method used to overcome it: Non-Deep Simple, Intermediate Simple level, Non-Deep Complex, and Intermediate Complex can be overruled by Gibberellin application, however, it is needed specific applications of stratification; to Deep Simple and Deep Simple Epicotyl gibberellin application can or cannot to be able to break dormancy, and cold and heat stratification jointly must be used; Deep Complex only can overcome the dormancy by cold stratification, and gibberellin application does not work here. It is important to identify after the nature of the dormancy of the Hog Plum. Chart 02 summarizes the levels dormancy of morphophysiological. 
Chart 02: Summary and description of dormancy levels

\begin{tabular}{|c|c|c|}
\hline & \multicolumn{2}{|c|}{ Description } \\
\hline $\begin{array}{l}\text { Level of MPD* } \\
\text { Dormancy }\end{array}$ & Stratification & GA**** Application \\
\hline Non-deep simple & $\mathrm{H}$ or $\mathrm{C}^{* *}$ & Yes*** \\
\hline Intermediate simple & $\mathrm{H}$ and $\mathrm{C}$ & Yes \\
\hline Deep simple & $\mathrm{H}$ and $\mathrm{C}$ & Some Cases \\
\hline Deep simple double & $\mathrm{C}+\mathrm{H}+\mathrm{C}$ & $?$ \\
\hline Non-deep complex & $\mathrm{C}$ & Yes \\
\hline Intermediate complex & $\mathrm{C}$ & Yes \\
\hline Deep complex & $\mathrm{C}$ & Not \\
\hline
\end{tabular}

Source: Adapted from Baskin and Baskin (2004)

\section{METHODOLOGY}

Firstly, papers were chosen from specific datasets (Scielo, Springer, Embrapa Dataset, Google Scholar as well as Theses and Dissertations repository of UFLA - Universidade Federal de Lavras). Secondly, the following key-words were searched for each of this dataset: "S. mombin Germination", "S. mombin Dormancy", "Dormancy" and "Germination". Sometimes, one of these words was substituted for its Portuguese correspondents and its synonyms to get wider and better outcomings. Finally, the results were noted and analysed.

\section{RESULTS AND DISCUSSION}

Remembering the Baskin`s scheme (BASKIN \& BASKIN, 2004) to classifying Seed Dormancy, there are three hierarchical layers: classes, comprising levels, containing types. The big deal of this work is to identify which kind (mainly class and level) of dormancy applies to Hog Plum and whether it's possible to infer it from the nowadays available literature.

It is believed today that mechanical restriction caused by the diaspores of Yellow Mombin is the only reason why embryo has difficulty to emerge, in such a way that is the cause of dormancy in this member of the genus Spondias. Some researches point out another prospect. First, Baskin and Baskin (2004) pinpoint that "Mechanical Dormancy", as it is most known, is an outcome of the non-deep Physiological Dormancy (PD), because of the low potential to growing of embryo, and, thereat, that class is not included in the newer classification scheme, being regarded as a non-deep PD component. Following this line, despite the fact Hog Plum has a horny and hard endocarp, it is only a consequence of its 
failure to develop, therefore embryo component is only one problem to deal with as well, not the main cause of that. Further, Carvalho et al. (1998), analyzing some tropical fruits native from Latin America, realize that even enclosure in the same structure (endocarp), each of real (in contrast with the endocarp - the unity of dispersion) seeds "maintain its individuality, mainly concerning days needed to germinate", which reinforces the idea that hog plum coat is not, at least, the only sake for its dormancy (AZEVEDO et al., 2004).

Either physical and combinational dormancy probably is not present in this specie. In the first class, the seed (or dispersion unit) coat blocks the water uptake, preventing the subsequent development of seeds. On the other hand, in the combinational dormancy, germination is blocked by physiological reasons as well. That is a common perspective in the scientific literature (FADIMU, et al., 2014; OYEBAMIJI et al., 2014), and, for it, several works assign enhancing on germinative parameters to scarification. However, it was found that $S$. mombin pericarp does not act as an impermeable wall. In fact, it had, after 72 hours, in research using blotting paper, the content of water around 70\% (CARVALHO and NASCIMENTO, 2020), therefore physical and combinational dormancy cannot be present in this Anacardiaceae, and any scarification treatment has a significant effect at all.

Morphological dormancy is characterized by the small size of the embryo, avoiding the germination at that time, but not cut down the capacity of germination at all, because if it is given time enough, the process can be concluded normally (FINCH-SAVAGE and LEUBNER-METZGER, 2006). Carvalho and Nascimento (2020), realize that storage in environmental temperature, Hog plum diaspores gets faster and even over the germination, indicating that time was the only factor needed to break dormancy and point toward a morphological dormancy. Besides, it was found that heat stratification during seven days (time to allow the embryo mature) at $30 \mathrm{o} \mathrm{C}$, after imbibition and heating in an oven, has a significative effect in the Index of Velocity of Emergence (IVE) compared with the control treatment, however, in the Percentage of Germination, this distinction was not found (SILVA, 2003). This difference can be due to the drastic treatments, which cause the death or damage of the embryo, but, despite this, the scarification is effective to reduce the time to germination, entailing morphological dormancy as well. Similar results were found to Spondias tuberosa, Arr. Câm., where after 120 days has obtained a huge germination rate as well as evenness in this process (LOPES et al, 2009). It is important to pinpoint, nonetheless, that few reliable papers concerning this topic were published. Thus, later researches are necessary to corroborate this hypothesis. 
Morphophysiological or physiological dormancy may be the predominant cause of the low germination in Hog plum. Research findings indicated that, if seeds Yellow mombin has time enough under environmental temperature, its germinations get faster and more even (CARVALHO and NASCIMENTO, 2020), namely, dormancy is naturally overruled, and morphological dormancy probably is present in this fruit once it occurs when the embryo is underdeveloped, and only time can overcome it. It is important to pinpoint, nonetheless, that some studies point out that scarification (both mechanical and chemical) can enhance the germination percentage (FADIMU et al., 2014; OYEBAMIJI et al., 2014; MARTIN et al., 2019), what can only be explained by non-deep physiological dormancy once this method (scarification) is suitable to break this level of dormancy (BASKIN and BASKIN, 2008). It has been found in related species, as Spondias Dulcis and Spondias pinnata, that scarification is an applicable treatment to get around dormancy problem as well as in S. mombin (DEY et al, 2016; SOUZA et al, 2020). Further, it is a matter of worth that researches indicate that GA (Gibberellins) application is not always effective breaking the dormancy of Hog plum and related species (SILVA, 2003; FLORES et al., 2006; DEY et al, 2016; SOUZA et al, 2020). According to the Revised Balance Hormone Model (KARSSEN and LACKA, 1986), GA only stimulates germination not acting as a breaker dormancy agent, which instigates the hypothesis of non-deep PD. Using those two findings, we can deduce that morphophysiological is the more explanatory hypothesis concerning the Hog plum dormancy, as summarized in Chart 03.

Once it was inferred that morphophysiological dormancy probably exists in this species, it is necessary to identify its level. To do so, it is needed to remember the chart used before (chart 02). There, it is possible to note that when Heat and Cold stratification work isolate to break dormancy there is evidence of Non-Deep Simple level. As we have seen before, Silva (2003) and Carvalho and Nascimento (2020) has found exactly that, make the point of this level of dormancy. Furthermore, for Spondias tuberosa, Arr. Câm, the heat stratification using oven was efficient breaking dormancy (BARROS et al, 2018). However, it is important to emphasize that no one research accessing the joint action of the two types of stratification in Yellow Mombin was carried out up until now. Concerning the Gibberellin application, it is possible to note that only sometimes this process works (SILVA, 2003; FLORES, 2006), the same having been encountered for some other species (MELO et al, 2012; DEY et al, 2016; SOUZA et al, 2020), what can pinpoint to Non-Deep level of dormancy as well. After looking at all of this data, surely Deep Simple level of dormancy is present in Hog Plum. 
It can be noted as well that the majority of papers concerning the dormancy in Hog Plum does not use Baskin`s scheme of dormancy classification (SILVA, 2003; AZEVEDO et al., 2004; FLORES et al., 2006; FADIMU, et al., 2014; OYEBAMIJI et al., 2014; DEY et al., 2016; MARTIN et al., 2019). That is a significant problem once both uniformization, as well as organization, is an important aspect of scientific research, and without that, it is tough to figure out some properties of the subject. Specifically, in Hog Plum dormancy, the nature of dormancy has been smothered for it, hindering the scientific advance in this area. Therefore, it is important to foster seed researchers to adopt this classification system.

Chart 03: Summary of the Probably Present and not present Classes of Dormancy in Hog Plum.

Mechanical Dormancy Not Present Alone

Baskin and Baskin (2004)

Carvalho et al. (1998)

Physical Dormancy Not Present

Carvalho and Nascimento (2020)

Morphological Dormancy Probably Present

Carvalho and Nascimento (2020)

Silva (2003)

Lopes et al. (2009)

Physiological Dormancy

Probably Present

Carvalho and Nascimento (2020)

Fadimu et al. (2014)

Oyebamiji et al. (2014)

Martin et al. (2019)

Flores et al. (2006)

Source: Own Source (2020)

\section{CONCLUSIONS}

Dormancy is a great stalemate inflicting Hog Plum seeds. This work has shown that is 
possible to detect the nature of the dormancy in this specie using the available literature. However, there are no papers to analyse the joint action of Cold and Heat stratification, so it is necessary researches concerning this. It is important to emphasize as well that a great number of papers published on this issue always does not explain what the nature of dormancy inflicting Yellow Mombin or when that is the subject searched, show which is the outcomes. It is important as well to stimulate the use of Baskin`s dormancy classification. The experimental works searched exclude the majority of dormancy classes, as physical, combinational, physiological, and morphological, resting only morphophysiological which is probably the cause of dormancy. Furthermore, following the same lines, it was realized that the level of this dormancy is the Deep Simple level. Using this data, seed producers will be able to break more efficiently dormancy and researchers develop new technologies for it.

\section{REFERENCES}

ADEDIWURA, F.-J.; KIO, A.. Antidiabetic Activity of Spondias mombin Extract in NIDDM Rats. Pharmaceutical Biology, [S.L.], v. 47, n. 3, p. 215-218, mar. 2009.

ADEDOKUN, M.; OLADOYE, A.; OLUWALANA, S.; MENDIE, I.. Socio-economic importance and utilization of Spondias mombin in Nigeria. Asian Pacific Journal Of Tropical Medicine, [S.L.], v. 3, n. 3, p. 232-234, mar. 2010.

ADLER, G. H.; KIELPINSKI, K. A.. Reproductive Phenology of a Tropical Canopy Tree, Spondias mombin. Biotropica, Oshkosh, v. 32, n. 4, p. 686-692, 3 nov. 1999.

AYOKA, A. O.; AKOMOLAFE, R. O.; IWALEWA, E. O.; AKANMU, M. A.; UKPONMWAN, O. E.. Sedative, antiepileptic and antipsychotic effects of Spondias mombin L. (Anacardiaceae) in mice and rats. Journal Of Ethnopharmacology, [S.L.], v. 103, n. 2, p. 166-175, jan. 2006.

AYOKA, A.O; AKOMOLAFE, R.O; AKINSOMISOYE, O.S; UKPONMWAN, O.E. Medicinal and economic value of spondias mombin. African Journal Of Biomedical Research, [S.L.], v. 11, n. 2, p. 129-136, 8 fev. 2010.

AYOKA, A; AKOMOLAFE, R; IWALEWA, E; UKPONMWAN, O. Studies on the Anxiolytic Effect of Spondias mombin 1. (Anacardiaceae) Extracts. African Journal Of Traditional, Complementary And Alternative Medicines, [S.L.], v. 2, n. 2, p. 153-166, 22 mar. 2005.

AZEVEDO, D. de M.; MENDES, A. M. da S.; FIGUEIREDO, A. F. de. Característica da germinação e morfologia do endocarpo e plântula de taperebá (Spondias mombin L.) Anacardiaceae. Revista Brasileira de Fruticultura, [S.L.], v. 26, n. 3, p. 534-537, dez. 2004.

BARROS, R. T. et al . Conditioning in the promotion and uniformization of Umbu seed germination. Rev. Bras. Frutic., Jaboticabal , v. 40, n. 1, e-109, 2018. 
BASKIN, J. M.; BASKIN, C. C.. A classification system for seed dormancy. Seed Science Research, [S.L.], v. 14, n. 1, p. 1-16, mar. 2004.

BASKIN, J. M.; BASKIN, C. C.. Some considerations for adoption of Nikolaeva's formula system into seed dormancy classification. Seed Science Research, [S.L.], v. 18, n. 3, p. 131137, set. 2008 .

BEWLEY, J. D.. Seed Germination and Dormancy. The Plant Cell, [S.L.], p. 1055-1066, 1 jul. 1997.

CARVALHO, J. E. U. de; NASCIMENTO, W. M. O. do. Water absorption and physiological responses of hog plum tree diaspores to storage. Revista Brasileira de Fruticultura, [S.L.], v. 42, n. 3, p. 1-10, 2020.

CARVALHO, J.E.U de; NASCIMENTO, W.M.O. do; MÜLLER, C.H. Características físicas e de germinação de sementes de espécies frutíferas nativas da Amazônia. Belém: Embrapa-CPATU, 1998. 18p. (Embrapa CPATU. Boletim de Pesquisa, 203).

CORTHOUT, J.; PIETERS, L.A.; CLAEYS, M.; BERGHE, D.A. V.; VLIETINCK, A.J.. Antiviral ellagitannins from Spondias mombin. Phytochemistry, [S.L.], v. 30, n. 4, p. 11291130, jan. 1991.

DEY, K.; GHOSH, A.; DEY, A.N.; BHOWMICK, N.; BAURI, F.K.. Studies on seed germination and seedling behaviour of Indian hog-plum (Spondias pinnata) in response to different pre-sowing treatments. Seed Science And Technology, [S.L.], v. 44, n. 3, p. 642646, 31 dez. 2016.

FADIMU, O.Y.; IDOWU O.T.H.; IPINLAYE S.J. Studies on the dormancy and germination of stony fruits of hog plum (Spondias mombin) in response to different presoaking seed treatments. International Research Journal of Biological Sciences, Gujarat, v.3, n.6, p.57$62,2014$.

FADIMU, Y.O. et al., Effect of Some Combination of Phytohormones on Some Growth Parameters and Vitamin C, Carbohydrate, Protein and Chlorophyll Contents of Spondias Mombin (Linn) Seedlings. Ife Journal Of Science, Abeokuta, v. 14, n. 2, p. 397-403, jan. 2012.

FINCH-SAVAGE, W. E.; LEUBNER-METZGER, G.. Seed dormancy and the control of germination. New Phytologist, [S.L.], v. 171, n. 3, p. 501-523, 14 jul. 2006.

FLORES, B. C.; NASCIMENTO, W. M. O. do. Avaliação de Métodos para Superação de Dormência em Sementes de Taperebá. In: Seminário de Iniciação Científica da Embrapa, 13., 2009, Belém. Pesquisa e desenvolvimento tecnológico na formação do jovem cientista: anais. Belém: Embrapa Amazônia Orienta, 2009. v. 1, p. 1-4.

INNIH, S. O.; OMAGE, S. O.; OMAGE, K.. Hematinic effects of Spondias mombin and its protective role against the spleenotoxic effect of phenylhydrazine. Clinical Phytoscience, [S.L.], v. 6, n. 1, p. 1-9, 24 maio 2020.

KARSSEN, C. M.; LAÇKA, E.. A Revision of the Hormone Balance Theory of Seed 
Dormancy: studies on gibberellin and/or abscisic acid-deficient mutants of arabidopsis thaliana. Proceedings In Life Sciences, [S.L.], p. 315-323, 1986.

KUCERA, B.; COHN, M. A.; LEUBNER-METZGER, G.. Plant hormone interactions during seed dormancy release and germination. Seed Science Research, [S.L.], v. 15, n. 4, p. 281307, dez. 2005.

LOPES, P. S. N. et al . Superação da dormência de sementes de umbuzeiro (Spondias tuberosa, Arr. Câm.) utilizando diferentes métodos. Rev. Bras. Frutic., Jaboticabal , v. 31, n. 3, p. 872-880, Sept. 2009.

MARTINS, C. C.; SILVA, G. Z. da; DURIGAN, L. D.; VIEIRA, R. D.. Pregerminative treatments of yellow mombin (Spondias mombin L.) seeds. Ciência Florestal, [s.1.], v. 29, n. 1, p. 363, 4 abr. 2019.

MATTIETTO, R. A., LOPES, A. S., \& MENEZES, H. C.. Caracterização física e físicoquímica dos frutos da cajazeira (Spondias mombin L.) e de duas polpas obtidas por dois tipos de extrator. Brazilian Journal of Food Technolology, 13, 156-164, 2010.

MELO, A. P. C. de; SELEGUINI, A.; CASTRO, M. N.; MEIRA, F. de A.; GONZAGA, J. M. da s; HAGA, K. I.. Superação de dormência de sementes e crescimento inicial de plântulas de umbuzeiro. Semina: Ciências Agrárias, [S.L.], v. 33, n. 4, p. 1343-1350, 30 ago. 2012.

OSUNTOKUN, O. T.; OMOTUYI, O. I. Bacteriostatic and Bactericidal Mechanism of Novel Compound Isolated from Ethyl Acetate Stem Bark Extract of Spondias mombin Using Biomarker Repressor LexA gene on Escherichia coli and Bacillus subtilis. Journal Of Molecular Biomarkers \& Diagnosis, [S.L.], v. 09, n. 05, p. 1-7, 2018.

OYEBAMIJI, N. A.; FADIMU, O.y.; ADEDIRE, M.O.. Best Pre-Germination Techniques on Spondias mombin Linn. Seeds for Plantation Establishment. American-Eurasian J. Agric. \& Environ. Sci, Dutsin-Ma, v. 6, n. 14, p. 575-579, jun. 2014.

QUADROS, B. R. de; RIBEIRO, O. D.; RODRIGUES JÚNIOR, O. M.; NASCIMENTO, W. M. O. do; CAVARIANI, C.; COSTA, E. N.. Biometria do endocarpo de taperebá (Spondias mombin L. - Anacardiaceae). Revista Cultivando O Saber, Belém, v. 8, n. 3, p. 250-256, jun. 2015.

ROLSTON, M. P.. Water impermeable seed dormancy. The Botanical Review, [S.L.], v. 44, n. 3, p. 365-396, jul. 1978.

ROSBAKH, S.; BASKIN, C. C.; BASKIN, J. M.. Nikolaeva et al.'s reference book on seed dormancy and germination. Ecology, [S.L.], v. 101, n. 7, p. 1-17, 8 maio 2020.

SAUTU, A.; BASKIN, J. M.; BASKIN, C. C.; DEAGO, J.; CONDIT, R.. Classification and ecological relationships of seed dormancy in a seasonal moist tropical forest, Panama, Central America. Seed Science Research, [S.L.], v. 17, n. 2, p. 127-140, jun. 2007.

SILVA, Leandro Monteiro da. Hog plum tree (Spondias mombin L.) endocarps dormancy breakage. 2003. 66p. Dissertation - (Master Program in Phytotechny). Universidade Federal de Lavras, Lavras. 
SOUZA, F.X. de.; LIMA, R.N. Enraizamento de estacas de diferentes matrizes de cajazeira tratadas com ácido indolbutírico. Revista Ciência Agronômica, Fortaleza, v.37. n.2, p.189194. 2005.

SOUZA, P. H. M. de; RAGAGNIN, A. L. S. L.; RIBEIRO, R. C; SILVA, G. Z. da; ROCHA, D. I.; SILVA, D. F. P. da. Dormancy overcoming in seeds of cajá-manga (Spondias dulcis). Comunicata Scientiae, [S.L.], v. 11, p. 1-6, 2 jun. 2020.

SOUZA, T. V. de; TORRES, I. C.; STEINER, N.; PAULILO, M. T. S.. Seed dormancy in tree species of the Tropical Brazilian Atlantic Forest and its relationships with seed traits and environmental conditions. Brazilian Journal Of Botany, [S.L.], v. 38, n. 2, p. 243-264, 19 fev. 2015.

SOUZA, V. R.; ANICETO, A.; ABREU, J. P.; MONTENEGRO, J.; BOQUIMPANI, B.; JESUZ, V. A.; CAMPOS, M. de B. E.; MARCELLINI, P. S.; FREITAS-SILVA, O.; CADENA, R.. Fruit-based drink sensory, physicochemical, and antioxidant properties in the Amazon region: murici (byrsonima crassifolia (1.) kunth and verbascifolia (1.) dc) and tapereba (Spondia mombin Linn.). Food Science \& Nutrition, [S.L.], v. 8, n. 5, p. 23412347, 15 abr. 2020.

TIBURSKI, J. H.; ROSENTHAL, A.; DELIZA, R.; GODOY, R. L. de O.; PACHECO, S.. Nutritional properties of yellow mombin (Spondias mombin L.) pulp. Food Research International, [S.L.], v. 44, n. 7, p. 2326-2331, ago. 2011.

VALE, I. do; COSTA, L. G. S.; MIRANDA, I. S.. Espécies indicadas para a recomposição da floresta ciliar da sub-bacia do rio peixe-boi, pará. Ciência Florestal, Santa Maria, v. 24, n. 3, p. 573-582, jul./set. 2014. 